\title{
Agricultural Diversification in the Garhwal Himalaya: A Spatio-Temporal Analysis
}

\author{
Vishwambhar Prasad Sati (Corresponding author) \\ Professor of Geography, Government KRG Post Graduate Autonomous College \\ Gwalior, Madhya Pradesh, India \\ E-mail: sati.vp@gmail.com
}

Received: October 5, 2011

Accepted: November 16, $2011 \quad$ Published: February 1, 2012

doi:10.5539/sar.v1n1p77

URL: http://dx.doi.org/10.5539/sar.v1n1p77

\begin{abstract}
The Garhwal Himalaya represents a traditional agricultural society where more than $74 \%$ population largely depends on the cultivation of subsistence cereal crops to run their livelihood. Over the time, with the increase in human population and decrease in per capita land, the traditional subsistence agriculture could not fulfill food requirement. This was resulted in food insecurity and thus agricultural diversification began with the cultivation of cash crops - fruits, off-season vegetables and also of medicinal plants. Although, agro-ecological condition favours diversification of crops and agro-biodiversity is very high in the Garhwal region, the pace of diversifying cash crops for commercialization is tremendously low. Diversity in crops varies spatially - horizontal and vertical and temporally - rabi and kharif seasons. The highlands characterize high agro-biodiversity in comparison to the mid-slopes and the valley regions. Crop diversification index (CDI) of cereals and cash crops was calculated separately from the secondary dada. A case study of six villages was done to calculate cost-benefit analysis of cereals and cash crops. The purpose of this study is to investigate the potential of diversification - cereals as well as cash crops for livelihood sustainability in the Garhwal Himalaya.
\end{abstract}

Keywords: Diversification, Agro-ecology, Subsistence agriculture, Cash crop, Livelihood, Garhwal Himalaya

\section{Geo-Environmental and Socio-Economic Background of the Study Area}

The Garhwal Himalaya is located in the Indian Central Himalayan Region (ICHR), a part of Uttarakhand Himalaya, constitutes one of the most fragile ecosystems. The area ranges from $400 \mathrm{~m}$ to above $7000 \mathrm{~m}$ but human settlements are limited upto $3200 \mathrm{~m}$. Landscape constitutes four eminent features - valley regions, mid-altitudes, highlands, and perpetual snow area with varying degree of climatic conditions ranging from subtropical to temperate, alpine, and frigid. The major perennial rivers - the Ganges, Yamuna, and their numerous tributaries originate from this part of the Himalaya. Administratively, it is a division of Uttarakhand State, comprises seven districts - Chamoli, Rudraprayag, Pauri, Tehri, Uttarkashi, Dehradun, and Haridwar. In this paper, only five districts of the Garhwal Himalaya such as Chamoli, Rudraprayag, Pauri, Tehri, and Uttarkashi are included. These districts are mountainous and known as the mainland of the Garhwal Himalaya. Agriculture practices continue to be the main occupation of people of the Garhwal Himalaya as about $70 \%$ population gets direct and indirect employment from agriculture (2011). Agricultural development holds the key to provide livelihood to a significant segment of population and the overall development of the region by way of creating employment, generating income, and ensuring food security to the rural people. Here, agriculture is characterized by low yield due to traditionally cultivating cereals, inadequate capital formation, low investment, inadequate irrigation facility, and uneconomic size of the holdings. Cropping pattern has shown a changing trend in the Garhwal during the recent past. The area under paddy and wheat crops has increased in the mid-altitudes and the valleys. There is a marginal increase in the area under cash crops. The Garhwal Himalaya is an economically underdeveloped and ecologically fragile region of the country. Due to high proportion of area under perpetual snow, steep slops, forest, pasture, grazing and waste lands, only $12 \%$ area is put under cultivation. Low agricultural yield reflects the small size and scattered land holdings, difficult terrain, unfavorable climatic conditions for some crops, inadequate availability of improved inputs and technology, and lack of credit and marketing facilities (Dewan \& Bahadur, 2005). While, the state can sustain forestry and agriculture for the survival of the people, live in this rural and hilly area (Bisht, 2006). Per capita net sown area 
in the region is 0.089 ha compared to 0.166 ha at all India level. Small and marginal holdings below 1 ha constitute more than $85 \%$ of total holdings. Cropping pattern is dominated by the traditional and low productivity crops (mostly cereals), which occupy about $99 \%$ of the crop area, providing basic livelihood for a vast majority of the population. The scope to raise employment and income through industrialization is very little because of the fragile landscape and poor infrastructure. Due to this prevailing situation, the income and employment at small farms are not adequate. This is worsening over time due to increase in population and non-availability of other sources of prominent livelihoods. However, the region is endowed with certain climatic advantages which offer numerous opportunities for production of a variety of high value horticultural crops. The landscape features provide a greater opportunity to the agricultural diversification that is prominently essential for sustainable livelihood. It also leads for cultivation of varieties of cash crops including fruits of various kinds in all altitudinal zones. The present study examines the scope for raising income and employment from various categories of land holdings by diversification through cultivating off-season vegetable. The specific objectives are: (i) examining the extent, nature and pace of crop diversification, (ii) quantify role of diversification in agricultural growth, (iii) identifying the key drivers of crop diversification, and (iv) document policy constraints in accelerating the speed of agricultural diversification. This study was conducted through the collection of primary and secondary data from March 2008 to Feb 2009. District wise data on the area and the production of cereals and cash crops were gathered from secondary sources of the government records. Crops diversity was calculated through crop diversification index (CDI) i.e. \%age of total cropped area under ' $n$ ' crops divided by number of ' $n$ ' crops. Where ' $n$ ' denotes those crops which individually occupied at least $2 \%$ or more of the total cropped area in the districts. Primary data were gathered through case study of 6 villages located in the various altitudes. Households involving in growing cash crops were interview and semi-structured questionnaire was prepared for interview.

\section{Agricultural Diversification}

Agricultural diversification refers to the development of greater variety of agricultural crops within space and time. It takes place with an increase in population and a decrease in per capita cropland. A sustained economic growth, rising per capita income and growing urbanization are ostensibly causing a shift in the consumption patterns in favour of high-value food commodities like fruits, vegetables, dairy, poultry, products from staple food such as rice, wheat and coarse cereals. The demand for and supply of these commodities have grown much faster than those of food-grains (Kumar et al., 2003; Joshi et al., 2004a). Such a shift in consumption patterns in favour of high-value food commodities even among the poorest strata of the Indian society depicts an on-going process of transformation that is leading towards a 'silent revolution' of agricultural diversification. This revolution or process of transformation is also reflected in the rising exports of high-value agricultural products (Government of India 2003). The changing scenario of agriculture has forced the farming community and policy makers in agriculture to search for a more remunerative and viable crops. The diversification of agriculture towards non-food-grain and high value commodities has been the right answer for it, because these commodities have potential of income augmentation, employment generation, poverty alleviation and export promotion (Von Braun, 1995; Pingali \& Rosegrant, 1995; Jha, 1996; Ramesh Chand, 1996; Vyas, 1996; Delgado \& Siamwalla, 1999; Ryan \& Spencer, 2001 \& Joshi et al., 2004b). It is, therefore, important to diagnose the production-consumption linkages in the context of agricultural diversification. It will enquire identification of the driving forces that can alter production and consumption pattern. It is also important to understand how the production pattern is evolving itself in response to changes in the consumption pattern, in a scenario where smallholders dominate agriculture and a majority of them live in the rural areas (Joshi, n.a.).

\section{Patterns of Agricultural Diversification in Garhwal Region}

Garhwal Himalaya represents a hotspot in agro-biodiversity. Here, agricultural diversification is slowly picking up momentum in favour of high-value food commodities primarily to augment income rather than the traditional concept of risk management. The nature of diversification differs across regions due to existence of wide heterogeneity in agro-climatic and socio-economic environments. It was considered interesting to delineate the key regions and sub-sectors of agriculture where diversification was catching up fast. Crops, livestock, and forestry constitute the core sectors of agriculture. The crop sector is the principal income-generating source in agriculture followed by the livestock sector. It is depicted a steady diversification here with replacement of food-grain crops with nonfood-grain crops. Several non-food-grain crops such as fruits, vegetables, and medicines have substituted mainly coarse cereals in the farmers' pursuit for higher income. The government-supported programmes had promoted the cultivation of fruits and vegetables. Among others, watershed program had facilitated conservation of rainwater and gave higher priority to the cultivation of fruits and vegetables. Rice and wheat have replaced coarse cereals and pulses in this region and it is diversifying only 
marginally towards non-cereal commodities. Fruits and vegetables have been the traditional route for agricultural diversification in the Garhwal Himalayan Region. Whereas fruit cultivation has been adopted in a big way in the temperate belt, the same does not appear to enjoy any comparative advantage in non-temperate belt. Moreover, the fruits being grown in the non-temperate belt are losing market to substitute fruits grown in the plains. Within horticulture, diversification through off-season vegetables seems to possess great potential in most of the areas in both temperate and non-temperate belts of the Garhwal Himalayan Region. Climatic conditions in many parts of the Garhwal Himalaya are suitable to produce crops like tomato, peas, beans, cabbage, and capsicum in summer season (April to October). The price advantage makes it worthwhile to incur high production cost and transport off-season vegetables to distant consumer markets. There are many small pockets, which have attained economic progress by diversification through off season vegetables cultivation. During the post-green revolution period, fruits and vegetables performed impressively in the Garhwal Himalaya. It was due to the greater thrust to these commodities. To encourage the horticulture sector through coordinating production and processing of fruits and vegetables, National Horticultural Board was constituted in 1984 on the lines of National Dairy Development Board (NDDB). To strengthen food processing and promote their export, the Government of India, established the Agricultural and Processed Food Products Export Development Agency (APEDA). The main aim was to build links between Indian producers and the global markets. It yielded promising results. Table 1 shows district wise CDI of traditional and cash crops in the hill districts of Garhwal region. In terms of CDI in traditional crops, there is a slightly variation. The three districts - Chamoli, Rudraprayag, and Uttarkashi have comparatively less diversity i.e., 7.69 CDI while Pauri Garhwal and Tehri Garhwal have 7.14 CDI. In cash crops, CDI vary from 6.67 (highest) in Chamoli district to 9.09 (lowest) in Rudraprayag and Tehri Garhwal districts. Pauri Garhwal and Tehri Garhwal have 7.14 and 7.69 (moderate) CDI respectively.

\section{Spatio-Temporal Factors and Agricultural Diversification}

Spatio-temporal factors have a great impact on the agricultural diversification in the Garhwal Himalaya. On the other hand, diversity of crops varies according to an altitude and the cropping seasons. Generally, crops are grown in all three altitudinal zones - valleys, mid-altitudes, and the highlands and in the two cropping seasons rabi and kharif. Highest diversity of crops is found in the highland during the kharif season. The highlands produce traditional subsistence crops nomenclature as 'Barahnaza' (literally, '12 seeds') during the monsoon season when enough water remains available for growing various crops. It is further characterized by the vertical distribution of crops - valley regions, mid-altitudes and highlands, and provides support in maintaining agro-biodiversity. Until today, this system controls the livelihood of about $70 \%$ of people in the region. The traditional agricultural systems are the reservoirs of many crops and cultivars, most of which are still little known to the mainstream societies, and are better adapted than modern agricultural systems to environmental and social conditions (Altieri, 1995; Ramakrishnan \& Saxena, 1996). Recently, global changes can be noticed in the crop diversification as the practice of cultivating 'Barahnaja' has decreased particularly in the mid-slopes and low-lying areas. Distribution of major crops according to the agro-ecological zones is as follows:

\subsection{Valley Regions}

The valley regions comprise $<1000 \mathrm{~m}$ altitudes. Settlements and agricultural lands are found on the river terraces and along the roads. Area under farmlands is considerably low. Crop seasons fall one month earlier than to the mid-altitude and the highlands because of comparatively high temperature. Among cereal crops, wheat, barley, gram, masur, and mustard are grown during the rabi season - Oct/Nov to March/April and rice and maize are grown during kharif season - April/May to Sept/Oct. Similarly under cash crops, lemon, elephant citrus, ginger, garlic, and green leaves are grown during rabi season and onion, tomato, cucumber, pumpkin, beans, and green vegetables are grown during kharif season. Crops diversity under cash crops is higher than the cereals.

\subsection{Mid-Altitudes}

This region comprises between 1000 and 1600 m altitudes. Wheat, barley, gram, masur, and mustard crops are grown under the rabi season while rice, manuwa (finger millets), koni, jhangora, kulthi, bhatt, urd, tour, naurangi, rajama, sawa, and cheena are grown under the kharif season. Under cash crops, lemon, elephant citrus, mandarin, orange, ginger, garlic, and green vegetables are grown during the rabi season. During the kharif season, potato, cucumber, pumpkin, beans, pears, peach, nut fruits, and green vegetables are grown.

\subsection{Highlands}

The highlands are located $>1600 \mathrm{~m}$. Here, diversity in crops - cereals and cash crops are tremendously high. They maintain agro-biodiversity. Sowing and harvesting periods for rabi and kharif crops in the highlands slightly go one month late than the valley region. Under rabi crops, there are fourteen crops grown out of them five are cereals. Under kharif season, the total number of crops is twenty five and out them cereals are thirteen. 
The highest number of crops grow under kharif season in all agro-ecological zones shows that agriculture is rainfed. During the monsoon, enough rainwater is available in this region thus, maximum crops are grown. Table 2 shows agro-ecological zones, altitudes, main cropping seasons and major crops - cereals and cash crops grown in the Garhwal Himalaya.

\section{Traditionally Cultivating 'Barahnaja' and Agro-Biodiversity}

The practice of Barahnaja is the name of a sophisticated intercropping system of rain-fed hill farming. Mandua (finger millet), ramdana/chua (amaranthus), rajma (common kidney beans), ogal (buckwheat), urad (black gram), moong (green gram), naurangi (mix of pulses), gahath (horse gram), bhat (soybean), lobiya (French beans) kheera (cucumber), bhang (cannabis) and other crops are grown together in a mix which is finely balanced to optimise productivity, maintenance of soil fertility, conservation of crop-diversity, and is geared towards meeting diverse household requirements. Zardhari (2000) describes it as a traditional mixed farming system in which central Himalayan farmers grow about 100 varieties of paddy, 170 varieties of kidney beans, eight varieties of wheat, four varieties of barley and about a dozen varieties of pulses and oil seeds each year. In such traditional cultivation, farmers have to spend almost nothing on inputs, since seeds, organic fertilizer, and pest control are virtually free. Whenever they see that conditions are suitable, they would start planting. Crops are grown between 400 and 3,200 metres. Wheat, rice, mandua, and jhangora are the common crops in three ecological zones, while wheat is grown in almost all the four ecological zones with highest productivity in comparison to the other crops. Various pulses (e.g., "masur", Ervum lens "kulat", and Dolichos biflorus) are grown in the intercropping system during the two harvest seasons - early winter after the rainy season (millet) and mid-summer before the hot dry season (barley and wheat). Dry and wet rice, taro, pumpkins, beans, corn, ginger, chili, cucumbers, leafy vegetables, and tobacco are also grown. Potatoes have become an important cash crop, growing in areas unsuitable for other plants. In the upland areas, above 1,500 metres, the practice of cultivating 'Barahnaja' is common. The mid-slopes and the low-lying river valleys have undergone tremendous changes in cropping patterns as cultivation of paddy, wheat, and cash crops are recent trends. This has reduced agro-biodiversity in these areas.

In the Garhwal Himalaya, Barahnaja is conserved by the practice of crop rotation (Sati, 2009). In a year, more than twelve crops are grown in the different seasons. Under the cropping pattern, the total agricultural land is divided into two parts: Talli and Malli Sar, which is called Sar-system (Sati, 1993). From April-May till September-October, kharif crops are grown in the Talli sar. The main crops are paddy, Koni, and Jhangora. The millets are grown in the Malli sar in the same period under the kharif season. The millets are mandua (finger millet), ramdana/chua (amaranthus), rajma (common kidney beans), ogal (buckwheat), urad (black gram), moong (green gram), naurangi (mix of pulses), gahath (horse gram), bhat (soybean), lobiya (French beans) kheera (cucumber), bhang (cannabis), and Jwar-Bajura. After harvesting the kharif crops in the Talli sar, the rabi crops, wheat, barley and oilseeds are sown during October-November. From October-November till March-April after harvesting the millets, the land is given up to fallow in the Malli sar. The cropping pattern under these sars will be in reverse in the second year. Besides the Talli and Malli sar, in and around the settlements, the vegetables: cucumber, pumpkin, potato, egg plant, lady's finger, garlic and maize is planted during the rainy season. The fields are known as Bada and Pelwara (Sati, 1993b).

\section{Area and Production Patterns of Cereal Crops}

Garhwal region represents high diversity of crops with comparatively less area under it and low production. Major crops are wheat, rice, cereals, and maize. These crops characterize highest area and production and major food staples of the inhabitant of Garhwal region. In all the five hill districts of Garhwal region, these crops represent equal proportion in area and production. Table 3 shows area and production patterns of 13 crops in the hill districts of Garhwal. These crops are rice, wheat, barley, bhat, gahat, maize, manduwa, sawa, rajama, chana, massor, urd, arhar, and peas. It reveals that out of 13 crops, rice and paddy have highest area and production in all districts. This is followed by manduwa. The other crops are sparsely grown with low per ha yield.

\subsection{Cultivation of Cash Crops}

Cash crops represent a highly valuable commodity and have a high economic viability but in the study region, area under cash crops is considerably less even some areas represent no land under these crops. It is observed from table 4 that potato has highest area under cultivation in all hill districts of Garhwal region followed by rapeseed and mustard and than by chili. The area under these crops varies from one district to another, depending upon the availability of cropped land and agro-ecological conditions. There are more than fifteen cash crops grown in Garhwal region. These crops are chili, ginger, garlic, mango, citrus, apple, potato, onion, sesamum, rapeseed and mustard, soyabeen, tea, drugs narcotics, and plantation crops. Table 4 shows area under cash crops 
during 2003-2004.

\subsection{Why Diversification of Cash Crops?}

The Garhwal Himalaya provides a great scope for production of off-season vegetables. The vegetable farming varies from the valley regions to the mid-altitudes and the highlands according to terrain, slope, soil contents, and availability of water. On the mid-slope and highlands, potato is grown extensively, while on the terraces of valley regions, onion is the main vegetable. Besides, almost all variety of vegetables is grown in the entire basin, which has high economic value. The vegetable farming can be divided into two vertical zones according to the altitude. Potato is the main vegetable of the highlands, which is grown between $1500 \mathrm{~m}$ and $2200 \mathrm{~m}$. It is mostly grown on the gentle slope of the mid-altitudes and the highlands $\left(10-15^{\circ}\right)$. During the $1980 \mathrm{~s}$, the farmers of the region started intensive cultivation of potato and they are now able to export potato to the regional market. Along with cultivation of potato, the other vegetables and spices such as beans, ginger, cucumber, pumpkin, turmeric, and chili are also grown in this zone. These vegetables are locally consumed. Onions are grown in the lowlands, where the availability of water is ample. It is grown during the summer in different localities along the river terraces. Presently, the farmers are able to export onion in the regional markets (foothills of Shivaliks). These localities are found between $800 \mathrm{~m}$ and $1200 \mathrm{~m}$.

\subsection{High Production and Per Ha Yield of Cash Crops}

The author conducted a case study of the six villages (Table 5). These villages were selected on the basis of their altitude, varies from $550 \mathrm{~m}$ to $2200 \mathrm{~m}$. Comparative study of cereals (millets, wheat, and rice) and off-season vegetables (onion and potato) were carried out, which reveals area, production, and productivity of the cereals and off-season vegetables. It further denotes that off-season vegetables have high production and productivity both in the lowlands and the highlands than to the cereals (varies from 11.7 to 2.5 per ha yield respectively) while, the area under cereal crops is three folds than to the area under off-season vegetables. In contrast to the low proportion of land, production and productivity of off-season vegetables is notably high. For instance about 460 ha agricultural land is under cereal crops in Kulsari village $(1150 \mathrm{~m})$ productivity is 4.7 whereas, the land under cultivation of onion is 85 ha, productivity is 7.1. The proportion of land under off-season vegetables is comparatively high in the highlands with high productivity. In a highland village (Kwarad - $2200 \mathrm{~m}$ ), land under cereals is 380 ha and its productivity is 2.5 whereas, 180 ha land is devoted for off-season vegetables, which productivity is 10 (Sati, 2009).

\subsection{Comparatively High Income Earnings from the Cash Crops}

As it is well known that the region possesses suitable agro-ecological conditions for the production of off-season vegetables therefore, high variety of vegetables such as onion, ginger, garlic, capsicum, cauliflower, ladyfinger, cucumber, pumpkin, tomato and potato are grown here but the proportion of land under off-season vegetables is considerably low. With the efforts done by the government agencies and introduction of modern innovation on the farmlands, the land under cereal crops is being transformed either into the cultivation of off-season vegetables or under fruit crops. Table 6 shows income of the farmers from both cereal crops and off-season vegetables.

\section{Discussion and Conclusions}

Farmers are the principal actors in management of diversity. Decision making by the farmers in choice of component for their farms is influenced by environmental, socioeconomic, and cultural factors as well as political climate (Morin et al., 1998). Mixed crop-livestock systems may have the potential to maintain an ecosystem's healthy functioning and enable it to absorb not only the shocks to the natural resource base (Holling, 1995; Prein et al., 1998) but also those brought about by sudden changes in the economic environment (Luu, 1999). In the Garhwal region, the farming community has responded to the changing consumption patterns of consumers by diversifying its production towards high-value food commodities. Experiences from many developing countries have revealed about the changing production at the farm level due to altering dietary patterns (Barghouti et al., 2003; Dorjee et al., 2002). Besides rising income levels, the increasing infrastructural development has been identified as factors that triggered the process of agricultural diversification out from the arena of staple food production (Joshi et al., 2005; Pingali, 2004). As economies grow, there is a gradual movement out of subsistence food-crop production to a diversified market-oriented production system. The process of diversification out of staple-food production is triggered by rapid technological change in agricultural production, by improved rural infrastructure, and by diversification in food-demand patterns. The slowdown in income-induced demand growth for staple foods is accompanied by a shift of diets to higher-value foods such as meats, fish, fruits, and vegetables. Since agricultural diversification includes horizontal, regional, and vertical diversifications, Karama et al. (1992) identified several potential benefits of agricultural diversification: (1) As 
the results of agricultural diversification, increasing quantity and quality of foods and raw materials produced in diverse agro-ecological zones will provide more income for farmers, improve diet for the people, and reduce import demand; (2) Agricultural diversification will results in better utilization of natural resources; (3) Handling, marketing, and processing of more foods and raw materials resulting from diversification will increase value added, employment, and therefore alleviate poverty; (4) The increasing income and diversified sources of foods will reduce the demand for rice; (5) Quality processed products, resulting from vertical diversification and integration, will enhance the potential for exports and therefore will increase foreign exchange earnings. Development of the fruits and vegetables is highly dependent on technological change (Weinberger \& Lumpkin, 2007). Unfortunately, the Garhwal region is lacking in farmland technology. Modern innovation in the farming system could not be established here due to the fragility of terrain and remoteness of the areas whereas the region is highly endowed with diverse agro-ecological conditions. As a result of this, only one-tenth of total agricultural area is devoted to fruits and vegetables. Diversification may also have a beneficial effect on the environment, as it usually breaks existing cereal cropping practices, which are of questionable sustainability (Ali, 2000; Cassman \& Pingali, 1995). Furthermore fruits grown from trees and perennials are associated with permanent crop cover which limits soil erosion and land degradation. Agricultural diversity, including diversity in cash crops, can be noticed in the highlands throughout in the Garhwal Himalaya while it is comparatively low in the mid-altitudes and the low-lying river valleys. Currently, the changes in cropping patterns seem more pronounced in these two vertical landscapes. Low output from cereals, substantial cultivation of wheat, paddy, and off-season vegetables, high rate of population growth and literacy, large-scale emigration etc. are the major trends that marginalized cereals and subsequently reduced agro-biodiversity. On the other hand, the traditional practice of cereals is suitable in the prevailing agro-ecological conditions of the region. It is sustainable even in the adverse climatic conditions such as drought. In 1987, when there was drought throughout India, the Garhwal Himalaya enjoyed substantial production of subsistence crops (Sati, 2004). Cash crops, on the other hand, provides sustainable livelihood thus, able to augment employment, generating more income and controlling emigration. A sizeable proportion of agricultural land can be devoted to the cultivation of cash crops - fruits and off-season vegetables, particularly along the perennial streams' terraces where water for irrigation is available. Keeping agro-ecology and suitability in view, these crops need to be conserved in a balanced proportion of land so that the agro-biodiversity and food security can be maintained.

\section{Acknowledgements}

This paper is an outcome of the ICSSR Postdoctoral Fellowship No. 0202/036/2006/G. Fel., awarded during 2008-09. The author acknowledges the ICSSR contribution for commencing this study.

\section{References}

Ali, M. (2000). Dynamics of vegetables in Asia: a synthesis. In: M. Ali, ed. Dynamics of Vegetables in Asia. World Vegetable Center, Shanhua, Taiwan.

Altieri, M. A. (1995). Agro-ecology puts synergy to work to create self-sustaining agroecosystem, Ceres FAO Review, 154(27), 15-23.

Barghouti, S., Kane, S., \& Sorby. K. (2003). Poverty and agricultural diversification in developing countries. Washington, DC, USA: The World Bank (Memio).

Bisht, D. S. (2006). Poverty, Planning and Development - A Case Study of Uttaranchal State (submitted to the Planning Commission). Central Himalayan Institute. Dehradun. Trishul Publications, Dehradun.

Cassman, K. G., \& Pingali, P. L. (1995). Extrapolating trends from long term expetiments to farmers' fields: the case of irrigated rice systems in Asia. In: V. Barnette, R. Payne, and R. Steiner, eds. Agricultural Sustainability: Economic, Environmental and Statistical Considerations. John Wiley and Sons Ltd., New York.

Delgado, C. L., \& Siamwalla, A. (1999). Rural economy and farm income diversification in developing countries. pp. 126-143. In Food security, diversification and resource management: refocusing the role of agriculture (eds. G.H. Peters and Joachim Von Braun). Proceedings of twenty-third International Conference of Agricultural Economists. Brookfield, Vermont, USA: Ashgate Publishing Company.

Dewan, M. L., \& Jagdish Bhadur (Eds.) (2005). Uttaranchal: Vision and Action Programme. Concept Publishing Company, New Delhi.

Dorjee, K., Broca, S., \& Pingali, P. (2002). Diversification in South Asian agriculture: trends and constraints. In International Workshop in Agricultural Diversification in South Asia, MoB-NCAP-IFPRI, Paro.

Government of India. (2003). Indian economic survey: 2002-2003. New Delhi: Akalank Publications. 
Holling, C. (1995). Sustainability: The Cross-scale Dimension. In M. Munasinghe and W. Shearer, eds., Defining and Measuring Sustainability. IBRD/WB, Washington, D.C., Pp. 65-76.

Jha, D. (1996). Rapporteur's report on diversification of agriculture and food security in the context of new economic policy. Indian Journal of Agricultural Economics, 51(4), 829-832.

Joshi, P. K. n.a. Crop Diversification in India: Nature, Pattern and Drivers.

Joshi, P. K., Gulati, A. Birthal, P. S., \& Tewari, L. (2004). Agricultural Diversification in South Asia: Patterns, Determinants and Policy Implications. Economic and Political Weekly, 39(24), 2457-2468

Joshi, P. K., Gulati, A. Birthal, P .S. \& P. Parthasarthy Rao. (2004). Agricultural diversification and vertical integraion in India: will smallholders participate? MTID. International Food Policy Research Institute, Washington, DC. (Memio).

Karama, A. S., Erwidodo, D. A. Darmawan, \& Oyer, E. B. (1992). Agricultural Diversification and Its Impacts on Income Generation in Rural Areas. In proceeding of seminar and workshop on Poverty Alleviation With Sustainable Agricultural and Rural Development in Indonesia, organized by CASER and CIIFAD, Bogor.

Kumar, P., Mruthyunjaya, \&P. S. Birthal. (2003). Changing consumption pattern in South Asia. Paper presented in the International Workshop on Agricultural diversification and vertical integration in South Asia organized by FICCI-ICRISATIFPRI on 5-6 November 2003 in New Delhi.

Luu, L. T. (1999). Small-scale Aquaculture in Rural Development - Trends and Constraints. In FAO, 1999. Report of the Asia-Pacific Fishery Commission Ad hoc Working Group of Experts in Rural Aquaculture. FAO, Bangkok, Thailand.

Morin, S. R., Jean-Louis Pham, Sebastian, L. S., Abrigo, G.., Erasga,D., Bellon, M. R., Calibo, M., \& Sanchez, P. (1998). Integrating indigenous technical knowledge and on-farm conservation: Collaborative research in the Cagayan valley, Philippines. (unpublished paper, International Rice Research Institute- IRRI- Philippines)

Pingali, P. L. \& Rosegrant. M. W. (1995). Agricultural commercialization and diversification: processes and policies. Food Policy, 20(3), 171-186. http://dx.doi.org/10.1016/0306-9192(95)00012-4

Pingali, P. L. (2004). Agricultural diversification: opportunities and constraints. FAO Rice Conference. Rome, Italy: Food and Agricultural Organization of United Nations. 12-13. February 2004.

Prein, M., Oficial, R., Bimao, M., \& Lopez, T. (1998). Aquaculture for Diversification of Small Farms within Forest Buffer Zone Management: An Example from the Uplands of Quirino Province, Philippines. In P. Edwards et al., eds., Rural Aquaculture. CAB International, Chiang Mai, Thailand. 97-110.

Ramakrishnan, P. S., \& Saxena, K. G. (1996). Managing biodiversity for sustainable development in the Himalaya, in Ramakrishnan, P S; Purohit, A N; Saxena, K G; Rao, K S; Maikhuri, R K (Ed), Conservation and Management of Biological Resources in Himalaya, IBH, Oxford, Pp 5-26.

Ramesh Chand. (1996). Diversification through high-value crops in western Himalayan Region: Evidence from Himachal Pradesh. Indian Journal of Agricultural Economics, 41(4), 652-663.

Ryan, J. G., \& Spencer, D. C. (2001). Future challenges and opportunities for agricultural R\&D in the Semi-Arid Tropics. Patancheru 502 324, Andhra Pradesh, India: International Crops Research Institute for the Semi-Arid Tropics.

Sati, V. P. (2009). Conservation of Agro-Biodiversity through Traditionally Cultivating 'Barahnaja' in the Garhwal Himalaya. MF Bulletin, IX(2), July 2009.

Sati, V. P., \& Kumar, Kamlesh. (2004). Uttaranchal: Dilemma of Plenties and Scarcities. New Delhi. Mittal Publication.

Sati, V. P. (1993a, b). Cropping Pattern in the Hill Environment of the Garhwal Himalaya. (A case study of a village). National Geographer, XXVIII(1), 31-37. website: www.mtnforum.org

Sati, Vishwambhar Prasad, \& Singh, R. B. (2009). Migration and Agrarian Changes in Mountain Regions - A Case Study of the Pindar Basin of Uttarakhand Himalaya. Annals of NAGI, 29(1), 20-33

Sati, Vishwambhar Prasad. (2009). Traditional Farming Systems and Sustainability Issues: a Case for the Garhwal Himalaya, India. Peer Reviewed Proceedings of the Fourth International Scientific Conference 'Rural Development 2009' Transitions Towards Sustainability 15-17 of Oct 2009, Lithuanian University of Agriculture. Pp. 399-407. 
Von Braun, Joachim. (1995). Agricultural commercialization: impacts on income and nutrition and implications for policy. Food Policy, 20(3), 187-202. http://dx.doi.org/10.1016/0306-9192(95)00013-5

Vyas, V. S. (1996). Diversification in agriculture: concept, rationale and approaches. Indian Journal of Agricultural Economics, 51(4).

Weinberger, K., \& T. A. Lumpkin, (2007). Diversification into horticulture and poverty reduction: a research agenda. World Development, 35(8), 1464-1480. http://dx.doi.org/10.1016/j.worlddev.2007.05.002

Zardhari, V. (2000). Barahnaja - twelve food grains: traditional mixed farming system'. Leisa India, 2(3), 25.

Table 1. CDI in the Garhwal Region

\begin{tabular}{|c|c|c|c|c|c|}
\hline \multirow{2}{*}{ S. No. } & \multirow{2}{*}{ District } & \multicolumn{2}{|c|}{ CDI } & \multicolumn{2}{c|}{ Cropped land (ha) } \\
\cline { 3 - 6 } & & Traditional Crops & Cash Crops & Traditional Crops & Cash Crops \\
\hline 1 & Chamoli & 7.69 & 6.67 & $51730(15.1)$ & $3744(20.8)$ \\
\hline 2 & Pauri Garhwal & 7.14 & 7.14 & $124388(36.4)$ & $3151(17.5)$ \\
\hline 3 & Rudraprayag & 7.69 & 9.09 & $32980(9.6)$ & $745(4.1)$ \\
\hline 4 & Tehri Garhwal & 7.14 & 9.09 & $44143(12.9)$ & $5582(31.0)$ \\
\hline 5 & Uttarkashi & 7.69 & 7.69 & $88953(25.9)$ & $4780(26.6)$ \\
\hline
\end{tabular}

Source: Raw data were collected from the District Statistical Diary (DSD) 2008

Note: figures in parentheses are \%ages

Table 2. Spatio-Temporal Distributions of Major Crops

\begin{tabular}{|c|c|c|c|c|}
\hline \multirow{2}{*}{$\begin{array}{c}\text { Agro-ecological } \\
\text { zones }\end{array}$} & \multirow{2}{*}{$\begin{array}{c}\text { Altitud } \\
\text { es (m) }\end{array}$} & \multirow{2}{*}{$\begin{array}{c}\text { Main cropping } \\
\text { season }\end{array}$} & \multicolumn{2}{|c|}{ Major crops grown } \\
\hline & & & Cereals & Cash crops \\
\hline \multirow{2}{*}{ Valley regions } & \multirow{2}{*}{$<1000$} & $\begin{array}{c}\text { Rabi } \\
\text { (Oct/Nov - } \\
\text { March/May) }\end{array}$ & $\begin{array}{l}\text { Wheat, barley, gram, } \\
\text { masur and mustard }\end{array}$ & $\begin{array}{l}\text { Lemon, elephant citrus, } \\
\text { ginger, garlic, and green } \\
\text { leaves }\end{array}$ \\
\hline & & $\begin{array}{l}\text { Kharif (April/May - } \\
\text { Sept/Oct) }\end{array}$ & Rice and maize & $\begin{array}{c}\text { Onion, tomato, cucumber, } \\
\text { pumpkin, beans, and all green } \\
\text { leaves }\end{array}$ \\
\hline \multirow[b]{2}{*}{ Mid-altitudes } & \multirow[b]{2}{*}{$\begin{array}{c}1000 \\
-1600\end{array}$} & $\begin{array}{c}\text { Rabi } \\
\text { (Nov/Dec- } \\
\text { April/May) } \\
\end{array}$ & $\begin{array}{l}\text { Wheat, barley, gram, } \\
\text { masur, and mustard }\end{array}$ & $\begin{array}{l}\text { Lemon, elephant citrus, } \\
\text { mandarin, orange, ginger, } \\
\text { garlic, and green leaves }\end{array}$ \\
\hline & & $\begin{array}{c}\text { Kharif (May/June - } \\
\text { Oct/Nov) }\end{array}$ & $\begin{array}{l}\text { Rice, manduwa, koni, } \\
\text { jhangora, kulthi, bhatt, } \\
\text { urd, tour, naurangi, } \\
\text { rajama, sawa, and cheena } \\
\text { (Panicum miliaceum) } \\
\end{array}$ & $\begin{array}{l}\text { Potato, cucumber, pumpkin, } \\
\text { beans, pears, peach, nut fruits, } \\
\text { and all green leaves }\end{array}$ \\
\hline \multirow[b]{2}{*}{ Highlands } & \multirow[b]{2}{*}{$>1600$} & $\begin{array}{c}\text { Rabi } \\
\text { (Nov/Dec- } \\
\text { April/May) }\end{array}$ & $\begin{array}{l}\text { Wheat, barley, rai, and } \\
\text { mustard }\end{array}$ & $\begin{array}{l}\text { Lemon, elephant citrus, } \\
\text { mandarin, orange, ginger, } \\
\text { garlic, arbi, green leaves }\end{array}$ \\
\hline & & $\begin{array}{c}\text { Kharif (May/June - } \\
\text { Oct/Nov) }\end{array}$ & $\begin{array}{l}\text { Rice, jhangora, kodo, } \\
\text { Phaphra, chaulai, ogal, } \\
\text { kauni, (Fagopyum } \\
\text { esculentum), sawa, urd, } \\
\text { bhatt, naurangi, tour, uva, } \\
\text { (Hoycleum himalayanse) }\end{array}$ & $\begin{array}{l}\text { Potato, cucumber, pumpkin, } \\
\text { beans, egg plants, chili, pears, } \\
\text { peach, almond, apple, } \\
\text { almond, and nut fruits }\end{array}$ \\
\hline
\end{tabular}

Source: Primary collection 
Table 3. Area and production patterns of crops (\%age of cropped area)

\begin{tabular}{|c|c|c|c|c|c|c|c|c|c|c|}
\hline \multirow{2}{*}{ Crops } & \multicolumn{2}{|c|}{ Chamoli } & \multicolumn{2}{|c|}{ Pauri Garhwal } & \multicolumn{2}{|c|}{ Rudraprayag } & \multicolumn{2}{|c|}{ Tehri Garhwal } & \multicolumn{2}{|c|}{ Uttarkashi } \\
\hline & Area & Prod & Area & Prod & Area & Prod & Area & Prod & Area & Prod \\
\hline Rice & 23.60 & 23.21 & 20.46 & 21.07 & 32.28 & 34.26 & 22.39 & 19.60 & 17.85 & 29.06 \\
\hline Wheat & 29.50 & 22.30 & 29.45 & 24.76 & 32.33 & 28.81 & 35.43 & 28.12 & 28.19 & 32.44 \\
\hline Barley & 3.08 & 3.03 & 4.91 & 4.03 & 3.89 & 3.29 & 0.39 & 1.29 & 1.75 & 0.35 \\
\hline Bhatt & 0.05 & 0.02 & 0.01 & 0.01 & 1.13 & 0.71 & 0.10 & 0.01 & 0.04 & 0.06 \\
\hline Gahat & 0.87 & 0.58 & 2.50 & 1.40 & 0.57 & 0.32 & 1.36 & 1.75 & 2.96 & 0.77 \\
\hline Maize & 15.84 & 17.43 & 2.54 & 3.09 & 0.57 & 0.59 & 13.55 & 3.15 & 2.48 & 14.05 \\
\hline Manduwa & 21.04 & 26.64 & 21.78 & 27.61 & 20.48 & 24.41 & 12.77 & 18.95 & 18.76 & 12.89 \\
\hline Sawa & 4.49 & 6.12 & 14.87 & 16.38 & 7.49 & 7.22 & 5.91 & 25.17 & 23.41 & 4.89 \\
\hline Rajma & 0.06 & 0.04 & 0.30 & 0.22 & 0.29 & 0.05 & 4.97 & 0.41 & 0.97 & 4.35 \\
\hline Chana & - & - & 0.06 & 0.05 & - & - & 0.01 & 0.01 & 0.18 & 0.01 \\
\hline Masur & 0.37 & 0.17 & 0.09 & 0.05 & 0.07 & 0.03 & 0.54 & 0.31 & 0.71 & 0.17 \\
\hline Urad & 0.80 & 0.26 & 2.54 & 0.95 & 0.69 & 0.18 & 1.34 & 0.48 & 1.59 & 0.37 \\
\hline Arhar & 0.22 & 0.13 & 0.42 & 0.28 & 0.14 & 0.06 & 0.40 & 0.43 & 0.78 & 0.15 \\
\hline Peas & 0.01 & 0.01 & 0.02 & 0.02 & 0.01 & 0.01 & 0.77 & 0.27 & 0.27 & 0.37 \\
\hline
\end{tabular}

Source: DSD 2008

Abr. Prod $=$ Production

Table 4. Area under cash crops (\%age of Total Area) 2003-04

\begin{tabular}{|c|c|c|c|c|c|}
\hline Commodities & Chamoli & Pauri Garhwal & Rudraprayag & Tehri Garhwal & Uttarkashi \\
\hline Chilies & 4.81 & 22.31 & 15.57 & 8.78 & 1.84 \\
\hline Ginger & 0.16 & 0.86 & & 3.87 & 0.02 \\
\hline Garlic & 1.31 & 1.30 & 2.013 & 0.63 & 0.23 \\
\hline Mangoes & 0.05 & 1.78 & & 0.08 & \\
\hline Citrus fruits & 0.19 & 0.03 & & & 0.04 \\
\hline Apples & 0.03 & 0.03 & 0.54 & & 8.77 \\
\hline Others fruits & 0.08 & 0.44 & 0.81 & & 1.63 \\
\hline Potatoes & 66.77 & 19.42 & 16.64 & 23.52 & 44.94 \\
\hline Onions & 1.36 & 15.26 & 2.95 & 2.26 & 0.52 \\
\hline Others vegetables & 2.69 & 7.52 & 4.03 & 19.37 & 4.92 \\
\hline Sesamum & 0.72 & 3.68 & 2.28 & 8.29 & 14.14 \\
\hline $\begin{array}{c}\text { Rapeseed \& } \\
\text { mustard }\end{array}$ & 14.20 & 16.03 & 45.64 & 22.75 & 20.86 \\
\hline Soybean & 6.65 & 11.04 & 9.39 & 10.39 & 2.07 \\
\hline Tea & 0.29 & & & & \\
\hline $\begin{array}{c}\text { Drugs, narcotics } \\
\text { and plantation } \\
\text { crops }\end{array}$ & 0.67 & 0.29 & 0.13 & 0.05 & 0.02 \\
\hline
\end{tabular}

Source: DACNET website, Ministry of Agriculture, Government of India 
Table 5. Production (quintal) and Productivity of Traditional Crops and Vegetables (2003)

\begin{tabular}{|c|c|c|c|c|c|c|c|}
\hline \multirow{2}{*}{$\begin{array}{c}\text { Name } \\
\text { of case } \\
\text { study } \\
\text { village }\end{array}$} & \multirow{2}{*}{$\begin{array}{c}\text { Altitu } \\
\text { de } \\
\text { (M) }\end{array}$} & \multicolumn{2}{|c|}{ Traditional crops (millets, wheat and } & \multicolumn{2}{|c|}{ Vegetables (potato and onion) } \\
\cline { 3 - 8 } & $\begin{array}{c}\text { Area } \\
\text { devoted }\end{array}$ & Production & Productivity & $\begin{array}{c}\text { Area } \\
\text { devoted }\end{array}$ & \multicolumn{2}{|c|}{ Production } & $\begin{array}{c}\text { Produ } \\
\text { ctivity }\end{array}$ \\
\hline Dimri & 550 & 465 (ha) & $\begin{array}{c}1600 \text { (Rice } \\
\text { and wheat) }\end{array}$ & 4.4 & 55 (ha) & $\begin{array}{c}400 \text { (Onion and other } \\
\text { seasonal vegetables) }\end{array}$ & 7.2 \\
\hline Kulsari & 1150 & 460 (ha) & $\begin{array}{c}1700 \text { (Rice } \\
\text { and wheat) }\end{array}$ & 4.7 & 85 (ha) & $\begin{array}{c}600 \text { (Onion and other } \\
\text { seasonal vegetables) }\end{array}$ & 7.1 \\
\hline Kewer & 1200 & 510 (ha) & $\begin{array}{c}1850 \text { (Rice } \\
\text { and wheat) }\end{array}$ & 3.6 & 65 (ha) & $\begin{array}{c}500 \text { (Onion and other } \\
\text { seasonal vegetables) }\end{array}$ & 7.6 \\
\hline Lolti & 1800 & 370 (ha) & $\begin{array}{c}1005 \\
\text { (Millets) }\end{array}$ & 2.7 & 136 (ha) & $\begin{array}{c}1600 \text { (Potato and other } \\
\text { seasonal vegetables) }\end{array}$ & 11.7 \\
\hline Khainoli & 2100 & 385 (ha) & 970 (Millets) & 2.5 & 165 (ha) & $\begin{array}{c}1745 \text { (Potato and other } \\
\text { seasonal vegetables) }\end{array}$ & 10.5 \\
\hline Kwarad & 2200 & 380 (ha) & 945 (Millets) & 2.5 & 180 (ha) & $\begin{array}{c}1800 \text { (Potato and other } \\
\text { seasonal vegetable) }\end{array}$ & 10 \\
\hline
\end{tabular}

Source: Sati, 2009a

Table 6. Income from Cereal Crops and Off-Season Vegetables

\begin{tabular}{|c|c|c|c|c|}
\hline $\begin{array}{c}\text { Name of } \\
\text { village }\end{array}$ & $\begin{array}{c}\text { Altitude } \\
\text { (M) }\end{array}$ & $\begin{array}{c}\text { Number of families } \\
\text { involving with growing off } \\
\text { season vegetables }\end{array}$ & $\begin{array}{c}\text { Income from cereal } \\
\text { crops (Indian } \\
\text { INR.)* }\end{array}$ & $\begin{array}{c}\text { Income from } \\
\text { off-season vegetables } \\
\text { (Indian INR.) }\end{array}$ \\
\hline Dimri & 550 & 38 & $\begin{array}{c}2000-2500 \text { per season } \\
\text { per family }\end{array}$ & $\begin{array}{c}3000-3500 \text { per season } \\
\text { per family }\end{array}$ \\
\hline Kulsari & 1150 & 29 & $\begin{array}{c}2000-2500 \text { per season } \\
\text { per family }\end{array}$ & $\begin{array}{c}3000-3500 \text { per season } \\
\text { per family }\end{array}$ \\
\hline Kewer & 1200 & 13 & $\begin{array}{c}\text { 2000-2500 per season } \\
\text { per family }\end{array}$ & $\begin{array}{c}3000-3500 \text { per season } \\
\text { per family }\end{array}$ \\
\hline Lolti & 1800 & 22 & $\begin{array}{c}1000-1500 \text { per season } \\
\text { per family }\end{array}$ & $\begin{array}{c}4000-4500 \text { per season } \\
\text { per family }\end{array}$ \\
\hline Khainoli & 2100 & 26 & $\begin{array}{c}1000-1500 \text { per season } \\
\text { per family }\end{array}$ & $\begin{array}{c}4000-4500 \text { per season } \\
\text { per family }\end{array}$ \\
\hline Kwarad & 2200 & 28 & $\begin{array}{c}1000-1500 \text { per season } \\
\text { per family }\end{array}$ & $\begin{array}{c}4000-4500 \text { per season } \\
\text { per family }\end{array}$ \\
\hline
\end{tabular}

Source: Sati, 2009b

* 45 INR is equal to 1 USD (as per the rate in May 2010) 